\title{
The impact of mobile health on breast cancer patient's life and treatment: A systematic review
}

\author{
Solmaz Sohrabi ${ }^{*}$ (D) , Alireza Atashi ${ }^{2}$ (i) \\ ${ }^{1}$ MSc. in Medical Informatics, Department of Health Information Technology and Management, School of Allied Medical Sciences, Shahid \\ Beheshti University of Medical Science, Tehran, Iran \\ ${ }^{2}$ Department of E-Health, Virtual School, Tehran University of Medical Sciences, Medical Informatics Research Group, Department of Clinical \\ Research, Breast Cancer Research Center, Motamed Cancer Institute (ACECR), Tehran, Iran
}

\begin{tabular}{|c|c|}
\hline Article Info & A B S T R A C T \\
\hline $\begin{array}{l}\text { Article type: } \\
\text { Review }\end{array}$ & \multirow{2}{*}{$\begin{array}{l}\text { Introduction: Breast cancer rates have been increasing worldwide, } \\
\text { particularly among young women, suggesting important interactions } \\
\text { between genes and health behaviors. At the same time, mobile technology, } \\
\text { including smartphones applications (apps), has emerged as a new tool for } \\
\text { delivering healthcare and health-related services. In 2019, there were nearly } \\
670 \text { publicly available breast cancer apps designed to provide disease and } \\
\text { treatment information, to manage disease, and raise overall awareness. }\end{array}$} \\
\hline $\begin{array}{l}\text { Article History: } \\
\text { Received: 2021-04-20 } \\
\text { Accepted: 2021-08-17 } \\
\text { Published: 2021-09-01 }\end{array}$ & \\
\hline $\begin{array}{l}\text { MSc. in Medical Informatics, } \\
\text { Department of Health Information } \\
\text { Technology and Management, } \\
\text { School of Allied Medical Sciences, } \\
\text { Shahid Beheshti University of } \\
\text { Medical Science, Tehran, Iran }\end{array}$ & $\begin{array}{l}\text { Material and Methods: In order to conduct a review, the Medline, Scopus } \\
\text { and PubMed databases were searched with the keywords "mobile health", } \\
\text { "mobile health in electronics health", "breast cancer and electronic health"," } \\
\text { mobile health and breast cancer"," mobile health and breast cancer qualify } \\
\text { life" and their equivalent. Out of the } 60 \text { articles found, after the depth of the } \\
\text { criteria Inclusion in the study, } 16 \text { articles remained, which were reviewed } \\
\text { and given using PRISMA } 2020 \text { checklist. SPSS software v. } 22 \text { was used for } \\
\text { description analysis. }\end{array}$ \\
\hline Email:elnazfatemi143@gmail.com & \multirow{2}{*}{$\begin{array}{l}\text { Results: A total of } 16 \text { articles met the inclusion criteria and were included } \\
\text { in this review. All studies have determined the positive impact of } \\
\text { applications on cancer detection and clinical health outcomes. In addition, } \\
\text { more than half of mobile applications have multiple functions, such as } \\
\text { providing information, planning and education. Furthermore, most studies } \\
\text { examining patient satisfaction and quality improvement have shown that } \\
\text { users of healthcare applications are significantly more satisfied with life, } \\
\text { leading to better quality. }\end{array}$} \\
\hline $\begin{array}{l}\text { rds: } \\
\text { t Cancer } \\
\text { e Health } \\
\text { natic Review }\end{array}$ & \\
\hline & $\begin{array}{l}\text { Conclusion: The evidence of the studies which are included in this } \\
\text { systematic review is currently limited, but it suggests that the mobile apps } \\
\text { might be an acceptable information source for women with breast cancer } \\
\text { and lead to improved patient well-being. }\end{array}$ \\
\hline
\end{tabular}

Cite this paper as:

Sohrabi S, Atashi A. Impact of mobile health on breast cancer patient's life and treatment: A systematic review. Front Health Inform. 2021; 10: 88. DOI: 10.30699/fhi.v10i1.295

\section{INTRODUCTION}

Smartphone technology represents an opportunity to deliver practical solutions for people affected by cancer at a scale that was previously unimaginable, such as information, appointment monitoring, and improved access to cancer support services [1]. Mobile health (mHealth) apps can provide an accessible platform for self-management among breast cancer survivors, as they recover from not just the intensive cancer treatments, but also their associated side-effects [2]. Breast cancer is a discrediting disease and its treatment can bring genuine results that have a physical and mental effect. In particular, cancer treatment affects psychological capacity strongly. Lately, new advancements and eHealth have impacted medical services and inventive portable applications can be valuable instruments to convey intellectual exercise in the patient's home []. $]$. As of 2018, there were almost 600 freely accessible breast cancer apps designed to provide disease and treatment data, to oversee ailment, and to raise in general mindfulness and There are around 40,000 healthcare applications (apps) available for smartphones. Breast cancer self- 
care under the influence of chemotherapy is an important and effective factor in controlling and reducing the side effects of chemotherapy, which makes the patients pay more attention to chemotherapy and improve his quality of life. Due to the role of mobile phones in personal life and the obvious charms for self-care, designing self-care programs through mobile apps can help patients $[\underline{4}$, 5]. In other word, mobile health can play an important role in management. Taking care of cancer patients can support adherence to medication, the provision of cancer information and follow-up care after cancer treatment []ㅡ. Mobile health can help care for the symptoms and complications of cancer patients. Patients who use this method can manage their symptoms by mobile health as a simple and easy way. mHealth can be useful for monitoring at home that gives them self-confidence and lead to beneficial management of the side effects of the disease [4]. Most people with cancer want to have accurate information about their decisions, illness, treatment, and prognosis for treatment. Mobile phones have the ability to provide this information directly []․ Mobile health can also be a tool to provide personal information related to cancer treatment including laboratory results, notes, and doctor's appointments [7]. Patients with breast cancer follow structured follow-up programs after completing their initial treatment. These programs are usually offered in outpatient clinics of hospitals and their focus is on relapse diagnosis, management synergy, monitoring the effects of treatment, identifying psychological problems and social and ongoing support for patients and their families []. $92 \%$ of breast cancers are primary and the rate of five-year survival of primary breast cancer is $95 \%$ and average survival of 15 years of these patients is $82 \%$, so follow-up care services have an increasing number of patients and usually without increasing the relevant resources to be presented $[\underline{9}, \underline{10}]$. Follow-up care access is difficult for patients living in remote and rural areas; this makes the difference between urban and rural patients. In addition breast cancer patients have expressed the inadequate support for this few centers. This shows the current models of cancer follow-up services are not appropriate. mHealth is a good way for some aspects of cancer care [11]. Studies show associated health in support follow-up care has been successful for patients undergoing chemotherapy breast cancer [12]. Hence, the target of this studies was to decide how mobile applications are being utilized for breast cancer anticipation among women over the disease control continuum.

\section{MATERIAL AND METHODS}

In this study a systematic search of Medline, Scopus and PubMed was performed to identify relevant studies. Use the keywords "mobile health", "mobile health in electronics health", "breast cancer and electronic health", "mobile health and breast cancer", "mobile health and breast cancer qualify life" to find updates related to Medline, Scopus and PubMed databases. Created and searched between 2014 and 2020. During this period, more than 60 documentaries were reviewed and the relevant items were extracted according to the following criteria after the depth of the criteria:

(1) all studies on male breast cancer, due to the rarity of this disease in men;

(2) breast cancer detection and treatment studies;

(3) studies not performed on human subjects;

(4) mobile health in during treatment, after treatment.

Inclusion in the study, 16 articles remained. To select the documents used, the titles found by the search engine were first examined in terms of thematic relevance. The findings were divided in two groups of articles, thesis. Selection criteria after the thematic relationship, the items that were more completed than the others were selected as the reference used.

For thesis, the selection criteria were thematic relevance and availability. After reviewing the titles and abstracts, full text was selected applying predefined in- and exclusion criteria. Included ones were studies presenting multivariable models, with the aim to effects for breast cancer patients. After reviewing the title, the articles were evaluated in the next step in terms of the relationship between the abstract and the intended purpose. From the selected studies, the following information was extracted:

Authors, publication date, study objectives, study population, study design, interventions' features, outcome measures, and results. The documents retrieved from the search were sent to Endnote software and evaluated according to the set criteria. The selected cases were thoroughly studied and finalized. Inclusion criteria for the mobile apps to be included in the review were availability in English language; free of any cost to the user; and have an available numerical user rating on the corresponding mobile app store.

A secondary screening was performed following the installation of resulting apps meeting primary screening criteria. The secondary screening was conducted to identify apps that offered at least one of the six identified self-management resources for breast cancer survivors and quality of life. Apps purely about breast cancer awareness, fund raising, and general information were not included. The apps that failed installation or did not work as expected were also excluded. All apps retrieved by the initial search were screened independently for inclusion by two reviewers with expertise in the areas of breast cancer self-management and the evaluation of personal health apps. Each differences were resolved 
through a process of discussion and reconciliation to reach consensus. The studies evaluated independently by three reviewers, and in case of any disagreement, a bilateral discussion session held to reach a consensus.

\section{Research questions}

The aim of this review is to search the impact of mobile health in three metrics. The research questions addressed are as follows:

1. What are the applications of mobile health in these studies?

2. What are the most commonly usage of mobile health in quality of life for breast cancer patients?

3. How is the quality of these studies?

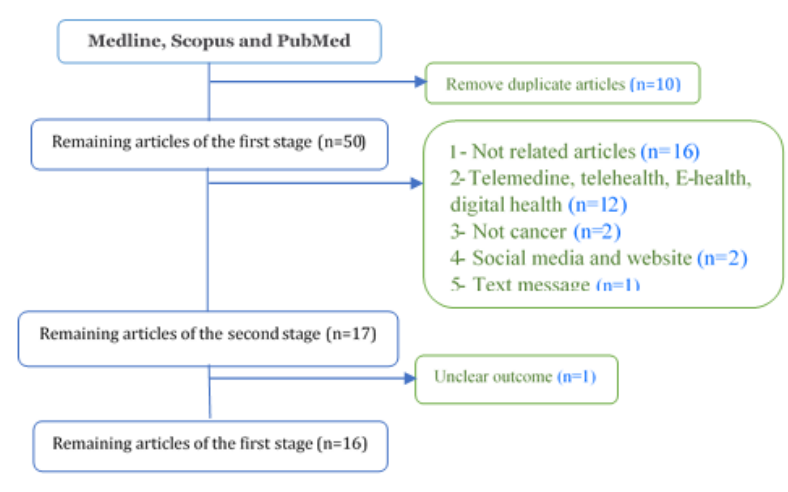

Fig 1: Article search flowchart

The number of authors of articles indicates the degree of participation of researchers. Many of the researches are the result of teamwork and as the participation and number of authors in the researches increases, it is a sign of the expansion of teamwork and the increase of collective wisdom. The results of the present study were a confirmation of this issue and showed the increase of participation and number of authors has a favorable effect on the quality of final research report, which is especially true for abstracts. The average of five authors indicates an acceptable level of participation in a study for each article. In most studies, the articles are reported by an average of three people. This indicates sensitivity and the need for collective wisdom and greater focus is for writing systematic reviews and meta-analysis.

\section{RESULTS}

Search results of all medical databases (English) in Iran has only 16 meta-analysis and systematic reviews by medical data in the period of 2014 to 2021. Table 1 , survey results the quality of systematic review articles and meta-analysis based on PRISMA tool shows the overall compliance rate of the quality of the articles survey with $72 \%$ report criteria,
PRISMA it was estimated. Most quality deficiencies in report section of the article method by $57 \%$ estimated. The most specific deficiency systematic and meta-analysis review reports case study related to errors in preliminary studies and errors resulting from the combination the results of these studies and the lack of reference to this there have been biases. Most of the articles found are related to the years were 2018 and (3.70\%) 2021, which in 6.43\% articles, especially the nationality of the writers, in none of them articles to be reviewed, authors with nationality no non-Iranians were found.

Some app characteristics of contents and features were categorized according to the functions and impacts. A number of mobile apps were developed for patients to exercise, which can have a positive effect on the patient's life. A number of mobile apps were developed for patients to exercise, which can have a positive effect on the patient's life. Mobile application has been used to rehabilitate patients and relieve their depressive states. Mobile application has been used to rehabilitate patients and relieve their depressive states. Table 1 shows the degree of compliance with the items listed in the Prism statement. The findings of the table indicate that the sections of objectives, title and combination of results with $90 \%, 98 \%$ and $75 \%$ of compliance, respectively, have the highest average in the criteria. Prism has been assigned to them, which shows the observance of the mentioned matters by the authors.

Table 1: Degree of observance of the items stated in the PRISMA statement in the abstract of the article under review

\begin{tabular}{|l|l|}
\hline Title & $90 \%$ \\
\hline Introduction/aims & $98 \%$ \\
\hline Methods & $57 \%$ \\
\hline Results & $75 \%$ \\
\hline Discussion & $89 \%$ \\
\hline
\end{tabular}

\section{DISCUSSION}

Most of the reasons for the inconsistency of the abstract of the reviewed articles with the PRISMA statement may be due to the lack of awareness of the authors of the PRISMA statement to report the results of the reviews and low level of familiarity with the scientific writing and evaluation of articles. The other side of the coin is the editors and editors of magazines. Unfortunately, most of the scientific journals in the country and even international journals do not provide any specific instructions for reviewing and judging the format of epidemiological articles. Another reason for this may be that in recent years more importance has been given to the quantity of reviews than to their quality. Thus, due to the need to provide systematic reviews and metaanalysis in providing complete and accurate reports, as well as the positive correlation between the number of receipts received and the actual 
application of the results of the study, the results are consistent. The items in this statement, which will improve the structure of the abstracts, apply to the inclusion of the Prism Handbook in the journal writing guide for article authors.

Table 2: Frequency of Reporting the Criteria of the PRISMA Statement in Articles

\begin{tabular}{|c|c|c|c|c|c|}
\hline Study & Year & Location & $\begin{array}{l}\text { Sample } \\
\text { Size }\end{array}$ & Type of Study & Out come \\
\hline $\begin{array}{l}\text { Lozano- } \\
\text { Lozano et al. } \\
{[\underline{13}]}\end{array}$ & 2020 & Spain & $\mathrm{N}=40$ & $\begin{array}{l}\text { Randomized } \\
\text { controlled } \\
\text { trial }\end{array}$ & $\begin{array}{l}\text { Both groups showed improved outcomes, but global QoL was significantly } \\
\text { better with BENECA mHealth and rehabilitation than BENECA mHealth alone } \\
\text { (mean difference, } 12.76 ; 95 \% \text { confidence interval } 4.85 ; 20.67 ; \mathrm{P}=0.004) \text {, with } \\
\text { a moderate-to-large effect size }(\mathrm{d}=72 \text { ). The proportion of participants } \\
\text { reporting reliable clinical improvement on global QoL at T2 was higher with } \\
\text { BENECA mHealth and rehabilitation than BENECA mHealth alone }(57.5 \% \text { vs } \\
26.3 \%, P=0.008) \text {. Improvement in subjective and objective upper-limb } \\
\text { functionality was also higher with BENECA mHealth and rehabilitation. }\end{array}$ \\
\hline $\begin{array}{l}\text { Siebenhüner } \\
\text { et al. [14] }\end{array}$ & 2021 & USA & $\mathrm{N}=83$ & $\begin{array}{l}\text { Self-care } \\
\text { cancer app } \\
\text { study }\end{array}$ & $\begin{array}{l}\text { A decrease in distress was associated with lower adherence to the app } \\
\text { intervention, whereas patients with moderate distress or an increase in } \\
\text { distress showed more adherence. }\end{array}$ \\
\hline $\begin{array}{l}\text { Brennan et } \\
\text { al. [10] }\end{array}$ & 2020 & Ireland & $\mathrm{N}=10$ & $\begin{array}{l}\text { Qualitative } \\
\text { study }\end{array}$ & $\begin{array}{l}\text { Self-driven rehabilitation; and visions for high-quality rehabilitation. } \\
\text { Regarding technology, participants reported a lack of mHealth options for this } \\
\text { clinical context and using non-cancer-specific applications and wearables. } \\
\text { Participants requested a mHealth tool from a reliable source that provides } \\
\text { exercise support. }\end{array}$ \\
\hline $\begin{array}{l}\text { Stanley et al. } \\
{[\underline{15}]}\end{array}$ & 2017 & USA & $\mathrm{N}=1434$ & $\begin{array}{l}\text { Retrospective } \\
\text { study }\end{array}$ & $\begin{array}{l}\text { Significant differences were found among patients visiting the cancer centre } \\
\text { versus the mobile mammography van. }\end{array}$ \\
\hline $\begin{array}{l}\text { Cairo et al. } \\
\text { [16] }\end{array}$ & 2017 & USA & $\mathrm{N}=127$ & $\begin{array}{l}\text { 2-group } \\
\text { control }\end{array}$ & $\begin{array}{l}\text { Had a significantly greater reduction in overall body mass index }(\mathrm{P}<0.01) \text {. The } \\
\text { app group also demonstrated statistically significant improvements in } \\
\text { "strenuous" physical activity }(\mathrm{P}=0.04) \text { and had significant improvement in } \\
\text { their dietary patterns }(\mathrm{P}<0.001)\end{array}$ \\
\hline $\begin{array}{l}\text { Sheikhtaheri } \\
\text { et al. [1] }]\end{array}$ & 2017 & Iran & $\mathrm{N}=33$ & Analytical & $\begin{array}{l}\text { help patients with breast cancer undergoing chemotherapy in managing side } \\
\text { effects and obtaining self-care skills }\end{array}$ \\
\hline Ollero et al. & 2017 & Netherlands & $\mathrm{N}=57$ & $\begin{array}{l}\text { Case- } \\
\text { controlled }\end{array}$ & $\begin{array}{l}\text { directed to the patient who is undergoing rehabilitation and allow to monitor } \\
\text { parameters of interest }\end{array}$ \\
\hline Nielsen et al. & 2020 & USA & $\mathrm{N}=30$ & $\begin{array}{l}\text { Cross- } \\
\text { sectional }\end{array}$ & $\begin{array}{l}\text { Five themes for desired mHealth physical activity intervention features during } \\
\text { chemotherapy for breast cancer were identified had best effect on patients }\end{array}$ \\
\hline Zhu et al. & 2018 & Australia & $\mathrm{N}=30$ & $\begin{array}{l}\text { Qualitative } \\
\text { study }\end{array}$ & $\begin{array}{l}\text { The qualitative interviews revealed that participants perceived the Breast } \\
\text { Cancer e-Support program to be helpful in enhancing knowledge, improving } \\
\text { confidence level, and promoting emotional well-being. Women also identified } \\
\text { access to tailored advice from experts and convenience as the benefits of this } \\
\text { program. Physical or psychological health status, stigma related with breast } \\
\text { cancer, and app instability were mentioned as the challenges to engagement }\end{array}$ \\
\hline $\begin{array}{l}\text { Chow et al. } \\
{[21]}\end{array}$ & 2020 & USA & $\mathrm{N}=40$ & $\begin{array}{l}\text { Pre-Post } \\
\text { study }\end{array}$ & $\begin{array}{l}\text { There was a significant decrease in general distress symptoms, as well } \\
\text { as symptoms of depression and anxiety, from baseline to post intervention }\end{array}$ \\
\hline $\begin{array}{l}\text { Sundberg et } \\
\text { al. [22] }\end{array}$ & 2017 & Spain & $\mathrm{N}=64$ & $\begin{array}{l}\text { Qualitative } \\
\text { study }\end{array}$ & $\begin{array}{l}\text { The intervention group rated significantly lower levels of fatigue and nausea at } \\
\text { the end of radiotherapy. Moreover, they had significantly less burden in } \\
\text { emotional functioning, insomnia, and urinary-related symptoms at the end of } \\
\text { treatment as well as } 3 \text { months later compared with the control group }\end{array}$ \\
\hline $\begin{array}{l}\text { Uhm et al. } \\
{[\underline{23}]}\end{array}$ & 2020 & Taiwan & $\mathrm{N}=24$ & $\begin{array}{l}\text { A 5-step } \\
\text { design } \\
\text { thinking } \\
\text { approach }\end{array}$ & $\begin{array}{l}\text { A total of } 8 \text { major themes including treatment, physical activity, diet, emotional } \\
\text { support, health records, social resources, experience sharing, and expert } \\
\text { consultation were identified. Minor themes included the desire to use the app } \\
\text { under professional supervision and a trustworthy app manager to ensure the } \\
\text { credibility of information. }\end{array}$ \\
\hline $\begin{array}{l}\text { Crafoord et } \\
\text { al. }[\underline{24}]\end{array}$ & 2020 & Sweden & $\mathrm{N}=74$ & $\begin{array}{l}\text { Mixed } \\
\text { methods }\end{array}$ & $\begin{array}{l}\text { Patients in the breast cancer group had a statistically significant lower } \\
\text { comorbidity score }(\mathrm{P}<.001) \text { and a higher self-reported education level } \\
(\mathrm{P}=.005) \text {. App as supportive during their treatments and described symptom } \\
\text { reporting in terms of diary keeping. Reporting symptoms encouraged and } \\
\text { supported reflection on their well-being and made patients more aware of } \\
\text { symptoms and what they should observe for }\end{array}$ \\
\hline $\begin{array}{l}\text { Fjell et al. } \\
{[\underline{25}]}\end{array}$ & 2020 & Sweden & $\mathrm{N}=75$ & $\begin{array}{l}\text { Randomized } \\
\text { controlled } \\
\text { trial }\end{array}$ & $\begin{array}{l}\text { The intervention group rated statistically significant less symptom prevalence } \\
\text { in nausea, vomiting, feeling sad, appetite loss and constipation. Overall } \\
\text { symptom distress and physical symptom distress were rated statistically } \\
\text { significant lower in the intervention group. Further, emotional functioning was } \\
\text { rated statistically significant higher in the intervention group. }\end{array}$ \\
\hline $\begin{array}{l}\text { Lim et al. } \\
{[\underline{26}]}\end{array}$ & 2021 & Korea & - & Development & professional support for monitoring and providing real-time feedback \\
\hline $\begin{array}{l}\text { Martin et al. } \\
\text { [27] }\end{array}$ & 2021 & France & $\mathrm{N}=9$ & $\begin{array}{l}\text { Qualitative } \\
\text { exploration }\end{array}$ & $\begin{array}{l}\text { The tested mHealth group challenge was associated with several positive } \\
\text { representations including well-being and good habit promotion and being a } \\
\text { motivational catalyser. Following feedback, modifications were implemented } \\
\text { into the mHealth challenge. }\end{array}$ \\
\hline
\end{tabular}


Table 3: Summary of the positive impact of mobile health on Breast cancer.

\begin{tabular}{|l|c|}
\hline Impact of mobile health & Percent \\
\hline Exercise & 30 \\
\hline Chemotherapy/Radiotherapy & 15 \\
\hline Mammography & 5 \\
\hline Rehabilitation & 20 \\
\hline Self-care & 20 \\
\hline Mental & 10 \\
\hline
\end{tabular}

Table 4: Frequency of Reporting the Criteria of the PRISMA Statement in Articles

\begin{tabular}{|c|c|c|c|c|c|c|}
\hline Author & Objects & Country & Year & Sample & Survey & Result \\
\hline $\begin{array}{l}\text { Kuhar et al. } \\
{[\underline{9}]}\end{array}$ & $\begin{array}{l}\text { Mobile app for symptom } \\
\text { management and } \\
\text { associated quality of life } \\
\text { during systemic treatment } \\
\text { in early tage breast cancer: } \\
\text { Nonrandomized controlled } \\
\text { prospective cohort study }\end{array}$ & Netherlands & 2020 & $\begin{array}{l}\text { Using mHealth } \\
\text { apps and their } \\
\text { impact on breast } \\
\text { cancer care. }\end{array}$ & $\begin{array}{l}\text { Impact using } \\
\text { mHealth on } \\
\text { breast cancer } \\
\text { care. }\end{array}$ & $\begin{array}{l}\text { Use of the app enabled } \\
\text { patients undergoing } \\
\text { systemic therapy for early } \\
\text { stage breast cancer to better } \\
\text { cope with symptoms which } \\
\text { was demonstrated by a } \\
\text { better global quality of life } \\
\text { and summary score after the } \\
\text { first week and by a better } \\
\text { summary score at the end of } \\
\text { treatment in the intervention } \\
\text { group compared to those of } \\
\text { the control group }\end{array}$ \\
\hline $\begin{array}{l}\text { Handa et al. } \\
{[\underline{11}]}\end{array}$ & $\begin{array}{l}\text { Effectiveness of a } \\
\text { smartphone application as } \\
\text { a support tool } \\
\text { for patients undergoing bre } \\
\text { ast cancer chemotherapy: } \\
\text { A randomized controlled } \\
\text { trial }\end{array}$ & Japan & 2020 & $\begin{array}{l}\text { Using mHealth } \\
\text { apps and their } \\
\text { impact on breast } \\
\text { cancer care }\end{array}$ & $\begin{array}{l}\text { Impact using } \\
\text { mHealth on } \\
\text { breast cancer } \\
\text { care, chemo } \\
\text { therapy. }\end{array}$ & $\begin{array}{l}\text { The BPSS app is a feasible } \\
\text { tool for patients with breast } \\
\text { cancer and might be useful as } \\
\text { a support tool for } \\
\text { information sharing } \\
\text { between patients and } \\
\text { medical staff in an effort to } \\
\text { optimize chemotherapy and } \\
\text { deliver suitable patient care } \\
\text { and support. }\end{array}$ \\
\hline $\begin{array}{l}\text { Zhu et al. } \\
{[\underline{20}]}\end{array}$ & $\begin{array}{l}\text { A mobile application of } \\
\text { breast cancer e-support } \\
\text { program versus routine } \\
\text { Care in the treatment of } \\
\text { Chinese women with breast } \\
\text { cancer undergoing } \\
\text { chemotherapy: Study } \\
\text { protocol for a randomized } \\
\text { controlled trial }\end{array}$ & Australia & 2018 & $\begin{array}{l}\text { Women with } \\
\text { breast cancer }\end{array}$ & $\begin{array}{l}\text { symptom } \\
\text { distress, } \\
\text { women as they } \\
\text { cope with the } \\
\text { unique } \\
\text { challenges of } \\
\text { breast cancer } \\
\text { and } \\
\text { chemotherapy }\end{array}$ & $\begin{array}{l}\text { The results of this } \\
\text { study will provide a better } \\
\text { understanding of the role of } \\
\text { self-efficacy and social } \\
\text { support in reducing } \\
\text { symptom } \\
\text { Distress and the credibility of } \\
\text { using a theoretical } \\
\text { framework to develop a BCS } \\
\text { intervention. }\end{array}$ \\
\hline $\begin{array}{l}\text { Dorri et al. } \\
\text { [28] }\end{array}$ & $\begin{array}{l}\text { A systematic review of } \\
\text { electronic health (eHealth) } \\
\text { interventions to improve } \\
\text { physical activity } \\
\text { in patients with breast can } \\
\text { cer }\end{array}$ & Iran & 2020 & $\begin{array}{l}\text { Women with } \\
\text { breast cancer }\end{array}$ & $\begin{array}{l}\text { Articles } \\
\text { comprise } \\
2304 \text { breast ca } \\
\text { ncer patients w } \\
\text { ith the mean } \\
\text { age of } 51 \text { years } \\
\text { and } 50 \% \text { were } \\
\text { conducted in } \\
\text { the USA }\end{array}$ & $\begin{array}{l}\text { The results show that } \\
\text { eHealth interventions can } \\
\text { improve the level of PA in } \\
\text { breast cancer patients. }\end{array}$ \\
\hline $\begin{array}{l}\text { Karim et al. } \\
{[\underline{29}]}\end{array}$ & $\begin{array}{l}\text { Mobile health applications } \\
\text { for improving the } \\
\text { sexual health outcomes } \\
\text { among adults with chronic } \\
\text { diseases: A systematic } \\
\text { review }\end{array}$ & Iran & 2020 & & $\begin{array}{l}\text { Sexual } \\
\text { problems in } \\
2304 \text { breast } \\
\text { cancer } \\
\text { patients }\end{array}$ & $\begin{array}{l}\text { All interventions were } \\
\text { delivered through websites, } \\
\text { and a positive effect on } \\
\text { sexual problems was } \\
\text { reported. }\end{array}$ \\
\hline
\end{tabular}


Table 5: Used of mobile application in other items

\begin{tabular}{|c|c|c|c|}
\hline & Smartphone applications & Text messages & Activity trackers \\
\hline $\begin{array}{l}\text { Appointment reminders, } \\
\text { Mental health support }\end{array}$ & Mobasheri et al. (2014) [5] & 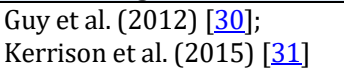 & \\
\hline Exercise tutorials or tracking & Harder et al. (2017) [32] & & Valle et al. (2017) [ \\
\hline Weight loss & McCarroll et al. (2015) [누] & & \\
\hline Symptom tracking & Patel et al. (2012) [35] & Mougalian et al. (2017) [36] & \\
\hline Health information & Alanzi et al. (2018) [37] & & \\
\hline Medication adherence & Mobasheri et al. (2014) [5] & Mougalian et al. (2017) [36]; & \\
\hline
\end{tabular}

Lim et al. start an application for edema self-care lymph nodes are present in women with breast cancer. This program has three electronic tools that are smartphones, tablets and laptops are available at Self-assessment, early detection and management of edema related symptoms lymph help [하] . A novel mobile app, was developed together with breast cancer patients to support self-management of arm and shoulder exercises following axillary treatment [32]. Further assessment in a randomized controlled trial is expected to provide objective proof on its clinical effectiveness. This will permit patients to upgrade the ease of use of the application, when suffering breast and lymph edema in other word using it to look at in the event that it is practical to utilize bWell as a coordinated piece of clinical consideration for breast cancer [32]. Studies showed that consistent and promising findings of interventions using mHealth apps that target care management in breast cancer. Among the categories of mHealth apps focusing on survivorship, mHealthbased interventions showed a positive effect by promoting weight loss, improving the quality of life, and decreasing stress [토]

Fu et al. [38] have examined in their study, mHealth assumes a critical function in improving self-care, patient-clinician communication, and access to health information. The optimal lymph flow health IT system (TOLF) is a patient-focused, web- and mobilebased educational and behavioral mHealth interventions focusing on safe, innovative, and pragmatic electronic assessment and self-care strategies for lymphedema symptom management. TOLF framework utilizing the electronic version of the instrument is able to assess patients' lymphedema side effects with high reliability and validity. TOLF system can survey deliver self-care mediations to enhance self-care strategies for lymphedema symptom management.

Zhou et al. surveyed whether a cyclic adjustment training (CAT) mediation conveyed through a mobile device can improve psychological resilience, and reduce mental strength and anxiety symptoms, in a population of post-surgical women with breast cancer. CAT had positive effects on improving psychological resilience and decreasing anxiety symptoms and depression, support for its use as an effective psychological management and intervention strategy in the beginning phases Longterm recovery in women after breast cancer surgery [39].

In Lee et al. [40] and Uhm et al. [23] studies, from mHealth in other, review and compare mobile portable impacts well-being health (mHealth) and pedometer with ordinary exercise program utilizing physical capacity and quality of life (QOL). Which the results showed overall, both the mHealth combined with pedometer and conventional exercise education utilizing a leaflet effective in improving physical function, physical activity, and QOL. Yanez et al. [41] survey two mobile programs in breast cancer patients, Latina breast cancer survivors who utilized the my guide and my health applications reported temporary decreases in symptom burden and improved breast cancer well-being over time, though there were no differential impacts between conditions. Findings suggest that technology may facilitate Latina breast cancer survivors commitment in care after breast cancer treatment.

The evidence from the studies included in this systematic review is currently limited but suggests that mobile apps for women with breast cancer might be an acceptable information source and lead to improved patient well-being. They can also be used to report symptoms and adverse treatment-related effects and promote self-care. However, the real utility of mobile apps for women undergoing breast cancer treatment is still uncertain. More evidencebased apps must be tested in future randomized clinical trials. There are numerous examples of mHealth interventions that can provide support for women following active breast cancer treatment, including the use of text message programs, smartphone applications and activity trackers $[\underline{42}$ 43].

Advances in digital technologies have created unprecedented opportunities to assess and improve health behavior and health outcomes. Mobile apps can inform breast cancer prevention across the continuum, given that breast cancer is a debilitating disease and conflict that requires care and posttreatment warnings, any program that can help patients have a better life is commendable. In mobile health for cancer, including the design of mobile applications for breast cancer has been able to play an important role in improving the patient's quality 
of life, assessing the patient's adaptation to the living environment after treatment. mHealth is defined as the use of mobile technologies, such as text messages, smartphone applications, and activity trackers, to support healthcare delivery [44]. Typically, mHealth interventions provide health education, biofeedback (e.g., heart rate, accelerometer) or motivation through personal or interpersonal challenges to numerous examples of mHealth interventions that can provide support for women following active breast cancer treatment, including the use of text message programs, smartphone applications and activity trackers.

An overview can be seen in Table 4 that mHealth is used to provide support for women with breast cancer. The majority of studies used mobile apps to target tertiary prevention, particularly clinical care coordination and health related quality of life for breast cancer survivors, as well as to improve the measurement and assessment of symptoms, behaviors, and risk. Many of the screened studies looked exclusively at the design, feasibility and acceptance of mobile health applications, but there was a significant lack of evidence for the efficacy of improve health-promoting behaviors. There are

utilizing patient facing applications to improve clinically relevant outcomes. An overview can be seen in Table 5.

\section{CONCLUSION}

Cancer patients often suffer from high levels of stress and distress. The mobile health app (mHealth) may be an innovative way to provide relaxation and mindfulness interventions for cancer patients.

\section{AUTHOR'S CONTRIBUTION}

All authors contributed to the literature review, design, data collection and analysis, drafting the manuscript, read and approved the final manuscript.

\section{CONFLICTS OF INTEREST}

The authors declare no conflicts of interest regarding the publication of this study.

\section{FINANCIAL DISCLOSURE}

No financial interests related to the material of this manuscript have been declared.

\subsection{7/1460458215577994 [PubMed]}

\section{REFERENCES}

1. Livingston PM, Heckel L, Orellana L, Ashley D, Ugalde A, Botti M, et al. Outcomes of a randomized controlled trial assessing a smartphone application to reduce unmet needs among people diagnosed with cancer (ACE). Cancer Medicine. 2020; 9(2): 507-16.

2. Kapoor A, Nambisan P, Baker E. Mobile applications for breast cancer survivorship and self-management: A systematic review. Health Informatics J. 2020; 26(4): 2892-905. PMID: 32842830 DOI: 10.1177/1460458220950853 [PubMed]

3. Vergani L, Marton G, Pizzoli SFM, Monzani D, Mazzocco K, Pravettoni G. Training cognitive functions using mobile apps in breast cancer patients: systematic review. JMIR Mhealth Uhealth. 2019; 7(3): e10855. PMID: 30888326 DOI: 10.2196/10855 [PubMed]

4. Houghton LC, Howland RE, McDonald JA. Mobilizing breast cancer prevention research through smartphone apps: A systematic review of the literature. Front Public Health. 2019; 7: 298. PMID: $31781525 \quad$ DOI: $\quad 10.3389 /$ fpubh.2019.00298 [PubMed]

5. Mobasheri MH, Johnston M, King D, Leff D, Thiruchelvam P, Darzi A. Smartphone breast applications: What's the evidence? Breast. 2014; 23(5): 683-9. PMID: 25153432 DOI: 10.1016/j.breast.2014.07.006 [PubMed]

6. Darlow S, Wen K-Y. Development testing of mobile health interventions for cancer patient selfmanagement: A review. Health Informatics J. 2016; 22(3): 633-50. PMID: 25916831 DOI:
7. Richards R, Kinnersley P, Brain K, McCutchan G, Staffurth J, Wood F. Use of mobile devices to help cancer patients meet their information needs in noninpatient settings: systematic review. JMIR Mhealth Uhealth. 2018; 6(12): e10026. PMID: 30552082 DOI: 10.2196/10026 [PubMed]

8. Halake DG, Ogoncho IM. The role of mobile health in supporting cancer prevention, detection, treatment and palliative care in low and middle income countries: A scoping review. Public Health Research. 2017; 7(6): 123-35.

9. Kuhar CG, Cepeda TG, Kovač T, Kukar M, Gorenjec NR. Mobile app for symptom management and associated quality of life during systemic treatment in early stage breast cancer: Nonrandomized controlled prospective cohort study. JMIR Mhealth Uhealth. 10.2196/17408 [PubMed]

10. Brennan L, Kessie T, Caulfield B. Patient experiences of rehabilitation and the potential for an mHealth system with biofeedback after breast cancer surgery: Qualitative study. JMIR Mhealth Uhealth. 2020; 8(7): e19721. PMID: 32687476 DOI: 10.2196/19721 [PubMed]

11. Handa S, Okuyama H, Yamamoto H, Nakamura S, Kato Y. Effectiveness of a smartphone application as a support tool for patients undergoing breast cancer chemotherapy: A randomized controlled trial. Clin Breast Cancer. 2020; 20(3): 201-8. PMID: 32201165 DOI: 10.1016/j.clbc.2020.01.004 [PubMed]

12. Fu MR, Axelrod D, Guth AA, Rampertaap K, ElShammaa N, Hiotis $K$, et al. mHealth self-care 2020; 8(8): e17408. PMID: 32427567 DOI: 
interventions: Managing symptoms following breast cancer treatment. Mhealth. 2016; 2: 28. PMID: 27493951 DOI: $\quad 10.21037 /$ mhealth.2016.07.03 [PubMed]

13. Lozano-Lozano M, Martín-Martín L, Galiano-Castillo N, Fernández-Lao C, Cantarero-Villanueva I, LópezBarajas IB, et al. Mobile health and supervised rehabilitation versus mobile health alone in breast cancer survivors: Randomized controlled trial. Ann Phys Rehabil Med. 2020; 63(4): 316-24. PMID: $31454561 \quad$ DOI: $\quad 10.1016 / j . r e h a b .2019 .07 .007$ [PubMed]

14. Siebenhüner AR, Mikolasek M, Witt CM, Barth J. Improvements in health might contradict adherence to mobile health interventions: Findings from a selfcare cancer app study. J Altern Complement Med. 2021; 27(S1): S115-23. PMID: 33788602 DOI: 10.1089/acm.2020.0111 [PubMed]

15. Stanley E, Lewis MC, Irshad A, Ackerman S, Collins H, Pavic D, et al. Effectiveness of a mobile mammography program. AJR Am J Roentgenol. 2017; 209(6): 1426-9. PMID: 28871806 DOI: 10.2214/AJR.16.17670 [PubMed]

16. Cairo J, Williams L, Bray L, Goetzke K, Perez AC. Evaluation of a mobile health intervention to improve wellness outcomes for breast cancer survivors. J Patient Cent Res Rev. 2020; 7(4): 313-22. PMID: $33163551 \quad$ DOI: $10.17294 / 2330-0698.1733$ [PubMed]

17. Sheikhtaheri A, Norouzi E, Sadoughi F. Developing a mobile-based self-care application for patients with breast cancer undergoing chemotherapy. Journal of Health Administration. 2019; 22 (4) :35-49.

18. Ollero J, Moral-Munoz JA, Rojas I, Banos O. Mobile health system for evaluation of breast cancer patients during treatment and recovery phases. International Conference on Bioinformatics and Biomedical Engineering. Springer; 2017.

19. Nielsen AM, Welch WA, Gavin KL, Cottrell AM, Solk P, Torre EA, et al. Preferences for mHealth physical activity interventions during chemotherapy for breast cancer: a qualitative evaluation. Support Care Cancer. 2020; 28(4): 1919-28. PMID: 31367917 DOI: 10.1007/s00520-019-05002-w [PubMed]

20. Zhu J, Ebert L, Liu X, Chan SW. A mobile application of breast cancer e-support program versus routine care in the treatment of Chinese women with breast cancer undergoing chemotherapy: Study protocol for a randomized controlled trial. BMC Cancer. 2017; 17(1): 291. PMID: 28446141 DOI: 10.1186/s12885017-3276-7 [PubMed]

21. Chow PI, Showalter SL, Gerber M, Kennedy EM, Brenin D, Mohr DC, et al. Use of mental health apps by patients with breast cancer in the united states: pilot pre-post study. JMIR Cancer. 2020; 6(1): e16476. PMID: 32293570 DOI: 10.2196/16476 [PubMed]

22. Sundberg K, Wengström Y, Blomberg K, HällebergNyman M, Frank C, Langius-Eklöf A. Early detection and management of symptoms using an interactive smartphone application (Interaktor) during radiotherapy for prostate cancer. Support Care
Cancer. 2017; 25(7): 2195-204. PMID: 28236145 DOI: 10.1007/s00520-017-3625-8 [PubMed]

23. Uhm KE, Yoo JS, Chung SH, Lee JD, Lee I, Kim JI, et al. Effects of exercise intervention in breast cancer patients: Is mobile health (mHealth) with pedometer more effective than conventional program using brochure? Breast Cancer Res Treat. 2017; 161(3): 443-52. PMID: 27933450 DOI: 10.1007/s10549-0164065-8 [PubMed]

24. Crafoord MT, Fjell M, Sundberg K, Nilsson M, LangiusEklöf A. Engagement in an interactive app for symptom self-management during treatment in patients with breast or prostate cancer: Mixed methods study. J Med Internet Res. 2020; 22(8): e17058. PMID: 32663140 DOI: 10.2196/17058 [PubMed]

25. Fjell M, Langius-Eklöf A, Nilsson $M$, Wengström $Y$, Sundberg K. Reduced symptom burden with the support of an interactive app during neoadjuvant chemotherapy for breast cancer: A randomized controlled trial. Breast. 2020; 51: 85-93. PMID: $32247251 \quad$ DOI: $\quad 10.1016 /$ j.breast.2020.03.004 [PubMed]

26. Lim JY, Kim JK, Kim Y, Ahn SY, Yu J, Hwang JH. A modular mobile health app for personalized rehabilitation throughout the breast cancer care continuum: Development study. JMIR Form Res. 2021; 5(4): e23304. PMID: 33847589 DOI: 10.2196/23304 [PubMed]

27. Martin E, Di Meglio A, Charles C, Ferreira A, Gbenou A, Blond $\mathrm{M}$, et al. Use of mHealth to increase physical activity among breast cancer survivors with fatigue: Qualitative exploration. JMIR Cancer. 2021; 7(1): e23927. PMID: 33749606 DOI: 10.2196/23927 [PubMed]

28. Dorri S, Asadi F, Olfatbakhsh A, Kazemi A. A systematic review of electronic health (eHealth) interventions to improve physical activity in patients with breast cancer. Breast Cancer. 2020; 27(1): 25-46. PMID: $31187411 \quad$ DOI: $\quad 10.1007 / \mathrm{s} 12282-019-00982-3$ [PubMed]

29. Karim H, Choobineh H, Kheradbin N, Ravandi MH, Naserpor A, Safdari R. Mobile health applications for improving the sexual health outcomes among adults with chronic diseases: A systematic review. Digit Health. 2020; 6: 2055207620906956. PMID: $32128234 \quad$ DOI: $\quad 10.1177 / 2055207620906956$ [PubMed]

30. Guy R, Hocking J, Wand H, Stott S, Ali H, Kaldor J. How effective are short message service reminders at increasing clinic attendance? A meta-analysis and systematic review. Health Serv Res. 2012; 47(2): 614 32. PMID: 22091980 DOI: $10.1111 / \mathrm{j} .1475-$ 6773.2011.01342.x [PubMed]

31. Kerrison RS, Shukla H, Cunningham D, Oyebode O, Friedman E. Text-message reminders increase uptake of routine breast screening appointments: A randomised controlled trial in a hard-to-reach population. Br J Cancer. 2015; 112(6): 1005-10. PMID: 25668008 DOI: $10.1038 /$ bjc.2015.36 [PubMed] 
32. Harder H, Holroyd P, Burkinshaw L, Watten P, Zammit C, Harris PR, et al. A user-centred approach to developing bWell, a mobile app for arm and shoulder exercises after breast cancer treatment. J Cancer Surviv. 2017; 11(6): 732-42. PMID: 28741202 DOI: 10.1007/s11764-017-0630-3 [PubMed]

33. Valle J, Godby T, Paul DP, Smith HM, Coustasse A. Use of smartphones for clinical and medical education. Health Care Management (Frederick). 2017; 36(3): 293-300.

34. McCarroll ML, Armbruster S, Pohle-Krauza RJ, Lyzen AM, Min S, Nash DW, et al. Feasibility of a lifestyle intervention for overweight/obese endometrial and breast cancer survivors using an interactive mobile application. Gynecol Oncol. 2015; 137(3): 508-15. PMID: 25681782 DOI: 10.1016/j.ygyno.2014.12.025 [PubMed]

35. Patel RA, Klasnja P, Hartzler A, Unruh KT, Pratt W. Probing the benefits of real-time tracking during cancer care. AMIA Annu Symp Proc. 2012; 2012: 1340-9. PMID: 23304413 PMCID: PMC3540467 [PubMed]

36. Mougalian SS, Epstein LN, Jhaveri AP, Han G, AbuKhalaf M, Hofstatter EW, et al. Bidirectional text messaging to monitor endocrine therapy adherence and patient-reported outcomes in breast cancer. JCO Clin Cancer Inform. 2017; 1: 1-10. PMID: 30657377 DOI: 10.1200/CCI.17.00015 [PubMed]

37. Alanzi TM, Alobrah A, Alhumaidi R, Aloraifi S. Evaluation of the SnapChat mobile social networking application for breast cancer awareness among Saudi students in the Dammam region of the Kingdom of Saudi Arabia. Breast Cancer (Dove Med Press). 2018; 10: 113-9. PMID: 30034251 DOI: 10.2147/BCTT.S166135 [PubMed]

38. Fu MR, Axelrod D, Guth A, Scagliola J, Rampertaap K, El-Shammaa N, et al. A web-and mobile-based intervention for women treated for breast cancer to manage chronic pain and symptoms related to lymphedema: Randomized clinical trial rationale and protocol. JMIR Res Protoc. 2016 ; 5(1): e7. PMID: 26795447 DOI: 10.2196/resprot.5104 [PubMed]

39. Zhou K, Li J, Li X. Effects of cyclic adjustment training delivered via a mobile device on psychological resilience, depression, and anxiety in Chinese postsurgical breast cancer patients. Breast Cancer Res Treat. 2019; 178(1): 95-103. PMID: 31342310 DOI: 10.1007/s10549-019-05368-9 [PubMed]

40. Lee H, Uhm KE, Cheong IY, Yoo JS, Chung SH, Park YH, et al. Patient satisfaction with mobile health (mHealth) application for exercise intervention in breast cancer survivors. J Med Syst. 2018; 42(12): 254. PMID: 30402781 DOI: 10.1007/s10916-0181096-1 [PubMed]

41. Yanez B, Oswald LB, Baik SH, Buitrago D, Iacobelli F, Perez-Tamayo A, et al. Brief culturally informed smartphone interventions decrease breast cancer symptom burden among Latina breast cancer survivors. Psychooncology. 2020; 29(1): 195-203. PMID: 31693265 DOI: 10.1002/pon.5281 [PubMed]

42. Odeh B, Kayyali R, Nabhani-Gebara S, Philip N. Optimizing cancer care through mobile health. Support Care Cancer. 2015; 23(7): 2183-8. PMID: $25649121 \quad$ DOI: $\quad 10.1007 / \mathrm{s} 00520-015-2627-7$ [PubMed]

43. Osborn J, Ajakaiye A, Cooksley T, Subbe CP. Do mHealth applications improve clinical outcomes of patients with cancer? A critical appraisal of the peerreviewed literature. Support Care Cancer. 2020; 28(3): 1469-79. PMID: 31273501 DOI: 10.1007/s00520-019-04945-4 [PubMed]

44. Qudah B, Luetsch K. The influence of mobile health applications on patient-healthcare provider relationships: A systematic, narrative review. Patient Educ Couns. 2019; 102(6): 1080-9. PMID: 30745178 DOI: 10.1016/j.pec.2019.01.021 [PubMed] 